\title{
ERRATUM \\ How precautionary is the policy governing the Ross Sea Antarctic toothfish (Dissostichus mawsoni) fishery? - ERRATUM \\ PETER A. ABRAMS
}

\begin{abstract}
doi:http://dx.doi.org/10.1017/S0954102013000801, Published by Cambridge University Press, 16 December 2014.
\end{abstract}

Key words: density dependence, ecological prediction, precautionary management, sustainable harvest: erratum

The author would like to correct two of a number of unapproved editorial changes made to this article at final proof stage.

The first change affected the section on ecosystem models (pp. 8-9) which addressed an article by Pinkerton and Bradford-Grieve (2012). This article came to the conclusion, "... it appears that Antarctic toothfish only have a moderate index of ecological importance in the food web of the Ross Sea shelf and slope."

The reference in question was subsequently revised and published as Pinkerton and Bradford-Grieve (2014). Its conclusion remains the same; page 9 of the on-line article states, "The analysis presented here suggests that Antarctic toothfish have moderate trophic importance in the Ross Sea foodweb as a whole."

This reference and its conclusion were completely removed from the published version of the article, and the more general assessment of ecosystem models of the Antarctic was reworded inappropriately. It was reported in the published version that the conclusion reached by Pinkerton and Bradford-Grieve "should be viewed with caution." This should have read as "should be viewed as highly speculative."
Secondly, the last sentence of the first full paragraph on the second column of page 10 was meant to compare the impacts of unmeasured mortality on population estimates for cod to those for Antarctic toothfish. This sentence should have read: "Mortality of discarded individuals and individuals that sustain injuries freeing themselves from longlines could have a larger effect on a species like D. mawsoni, which, based on its life history, must have a lower maximum population growth rate."

\section{References}

Abrams, P.A. 2014. How precautionary is the policy governing the Ross Sea Antarctic toothfish (Dissostichus mawsoni) fishery? Antarctic Science, 26, 3-13, 10.1017/S0954102013000801.

Pinkerton, M.H. \& Bradford-Grieve, J.M. 2012. Network characterisation of the food-web of the Ross Sea, Antarctica, Document WG-EMM-12/53, Commission for the Conservation of Antarctic Marine Living Resources.

Pinkerton, M.H. \& Bradford-Grieve, J.M. 2014. Characterizing foodweb structure to identify potential ecosystem effects of fishing in the Ross Sea, Antarctica. ICES Journal of Marine Science, 10.1093/ icesjms/fst230. 